\title{
The effect of oxygenated water in Diabetes Mellitus
}

\author{
Yvonne S. Handajani, ${ }^{1}$ Riki Tenggara, ${ }^{2}$ Fransiscus D. Suyatna, ${ }^{3}$ Charles Surjadi, ${ }^{1}$ Nelly T. Widjaja ${ }^{1}$ \\ ${ }^{1}$ Center for Health Research, Atma Jaya Catholic University, Jakarta \\ ${ }^{2}$ Departement of Interna, Faculty of Medicine, Atma Jaya Catholic University, Jakarta \\ ${ }^{3}$ Departement of Pharmacology, Faculty of Medicine, University of Indonesia, Jakarta
}

\begin{abstract}
Abstrak
Tujuan Mendapatkan gambaran pengaruh air oksigen terhadap diabetes mellitus.

Metode Penelitian ini menggunakan disain uji klinik acak tersamar ganda, dengan 108 subyek diabetes mellitus. Setiap kelompok dibagi secara acak menjadi 2 sub kelompok. Satu subkelompok diberikan air oksigen dan subkelompok lain diberikan bukan air oksigen dalam 2 tahap intervensi, 45 hari dan 90 hari. Variabel yang diukur adalah kadar gula darah dan malondialdehyde (MDA) dengan pengendalian enam faktor perancu : jenis kelamin, umur, merokok, olah raga, konsumsi vitamin dan status gizi.
\end{abstract}

Hasil Didapatkan bahwa konsumsi air oksigen selama 90 hari, dapat menurunkan kadar gula darah postprandial pada subyek diabetes mellitus. Kadar MDA pada subyek diabetes mellitus dengan status gizi normal, cenderung menurun pada subyek yang mengkonsumsi air oksigen selama 45 hari. Sebagian besar subyek merasa lebih sehat dan lebih segar setelah mengkonsumsi air oksigen.

Kesimpulan Air oksigen dapat meningkatkan proses penyembuhan subyek dengan diabetes mellitus. (Med J Indones 2009; 18: 102-7)

\begin{abstract}
Aim To examine those claims, i.e the effects of oxygenated water on hypertension and Diabetes Mellitus (DM).

Methods In this clinical trial, 108 subjects of Diabetes Mellitus were recruited. Each group was divided randomly into 2 subgroups. One subgroup was given oxygenated water and the other subgroup was given non-oxygenated water for 2 period of intervention, 45 days and 90 days. Measured variables were, blood sugar and malondialdehyde (MDA).

Results The study showed that oxygenated water could reduce post-prandial glucose in DM subjects. DM subjects with normal nutritional states, also had greater tendency of MDA reduction after consuming oxygenated water for 45 days. Most of subjects felt healthier after consuming oxygenated water.
\end{abstract}

Conclusion The consumption of oxygenated water could improve the healing process for patients with diabetes mellitus. (Med J Indones 2009; 18: 102-7)

Key words: oxygenated water, diabetes mellitus, $M D A$, free radicals

On the era of globalization, the development has happened in several sectors, such as economic, social, industrial, etc. It brings some impacts in the community, like diet pattern and life style. The alteration of life style is followed by a significant increase of prevalence of certain diseases, like diabetes mellitus and other chronic diseases.

Diabetes mellitus affects a large numbers of people in a wide range of ethnic groups and at all social and economic levels worldwide. The Prevalence of DM keep increases ing in the last two decades and estimated to increase continually. The American Diabetes Association estimate that the DM prevalence is about 7,4\% in 1995 and still increase to near $9 \%$ in 2025 . Thus, there is an urgent need for srategies to prevent the emerging global epidemic of type 2 diabetes. ${ }^{1}$

A steady stream of reports on a variety of populations have continued to highlight the explotion of type 2 diabetes in relation to lifestyle change, especially in diet. Appropriate nutrition is needed besides other healthy life style to reduce the social and economic burden of type 2 diabetes. ${ }^{1}$ 
Diabetes mellitus is a leading cause of morbidity and mortality, largely because of its vascular complications. The most common cause of death among people with diabetes today is atherosclerotic cardiovascular disease (CVD). The numerous potential mechanisms that could mediate premature atherogenesis in diabetes include oxidative stress. Factors that may promote oxidative stress in diabetes include antioxidant deficiencies and increased production of reactive oxygen species (ROS). ${ }^{2}$ The increase of free radical ectivities is associated with aldehyde production which is also reactive, the so called malondialdehyde (MDA). The increasing MDA, also generaly reflects the decrease of the bodies antioxidant capacity against free radical.

In the past several years, a number of oxygenated water beverages have been launched on the markets in Indonesia and other countries. After that, there are many reports about the benefit of oxygen water for human health, but there are still no convincing evidence. However, the people continue to use oxygen water because they believe that oxygenated water, can make better health, increase oxygen capacity in blood, and increase body endurance against polutan and drugs.

Research on oxygenated water in human is still lacking till now, but there are some research in animal such as rabbit which give us information that administration of oxygenated water to the rabbits with $45 \mathrm{mg} \mathrm{O}_{2} / \mathrm{L}$ concentration, make minimal increase consentration in abdomen. But, with 80 or $150 \mathrm{mg} \mathrm{O}_{2} / \mathrm{L}$ water, oksigen in abdomen increase by $20 \mathrm{mmHg}$, and in portal vein increase by $14 \mathrm{mmHg}$. Oxygen penetration occur difusily and are influence by physical factor and fisiological factors.

In this study, giving oxygen water to the DM patients was conducted under asumption that the intervention can reduce oxydative stress that already happend and can influence on blood glucose. It was carry out by performing fisical examination and laboratory examination such as fasting and after meal blood glucose, ureum, creatinin, lipid profile, rutin hematology, urinalysis, SGOT \& SPGT and chest $\mathrm{x}$-ray. as well as by measuring oxidative stress, before and after oxigen water consumption.

\section{METHODS}

There were 224 subjects consisted of 108 DM patients and 116 non DM subjects. All patients were selected by 12 doctors ( 7 of them work in Community Health Centers and the others as private general practitioners). The subjects were selected according to the following inclusion and exclusion criteria: fasting glucose $\geq 126$ $\mathrm{mg} / \mathrm{dl}$ and/or post-prandial glucose $\geq 200 \mathrm{mg} / \mathrm{dl}$ or under oral hypoglycemia therapy.

Exclusion criteria were: (1) DM with severe complication e.g. non ketotic hyperglycemic coma, diabetic ketoacidosis, (2) DM with other severe illness e.g. coronary heart disease, diabetic nephropathy, etc.

The subjects were randomly divided into 2 subgroups, one was given oxygenated water and the other was given non-oxygenated water (common potable water) for 2 periods of intervention, 45 days and 90 days. Each subject obtained 4 bottles of $235 \mathrm{ml}$ oxygenated water or non-oxygenated water everyday during this study. Then, the blood pressure, blood sugar and plasma malondialdehyde (MDA) contents were measured at the beginning of the study, after 45, and 90 days of intervention. The 6 confounding factors that might be correlated with the study, i.e.: sex, age, smoking, exercise, vitamin, and nutritional state were also put into analysis. Statistical Analysis was performed by the GLM ( General Linear Model) Repeated Measure. and Chi square (Pallant Julie, 20054, SPSS Inc, 19995).

\section{RESULTS}

In DM group, almost half of them were 51-59 yrs old, only graduated from junior and senior high school and they were not working. The demographic characteristics of the subjects who participated in the study are presented in Table 1.

The characteristic of each subjects related to confounding factors are shown in Tables 2 . 
Table 1. Demographic characteristic of the subject

\begin{tabular}{|c|c|c|}
\hline Sex & $\mathbf{n}$ & $\%$ \\
\hline Male & 44 & 40.7 \\
\hline Female & 64 & 59.3 \\
\hline Total & 108 & 100.0 \\
\hline \multicolumn{3}{|l|}{ Age } \\
\hline$\leq 50 \mathrm{yr}$ & 35 & 32.4 \\
\hline $51-59 \mathrm{yr}$ & 46 & 42.6 \\
\hline$\geq 60 \mathrm{yr}$ & 27 & 25.0 \\
\hline Total & 108 & 100.0 \\
\hline \multicolumn{3}{|l|}{ Education } \\
\hline No education & 42 & 38.9 \\
\hline Junior high school graduate & 24 & 22.2 \\
\hline Senior high school graduate & 27 & 25.0 \\
\hline Academy or University graduate & 15 & 13.9 \\
\hline Total & 108 & 100.0 \\
\hline \multicolumn{3}{|l|}{ Occupation } \\
\hline Not working & 45 & 41.7 \\
\hline Entrepreneur & 5 & 4.6 \\
\hline Goverment worker & 12 & 11.1 \\
\hline Employee & 19 & 17.6 \\
\hline Laborer & 2 & 1.9 \\
\hline Others (retired, housewife) & 25 & 23.1 \\
\hline Total & 108 & 100.0 \\
\hline
\end{tabular}

Table 2. Distribution of DM subjects related to confounding factors and intervention

\begin{tabular}{|c|c|c|c|c|c|c|}
\hline \multicolumn{2}{|c|}{ Confounding factors } & \multicolumn{2}{|c|}{$\begin{array}{c}\text { Non- } \\
\text { oxygenated } \\
\text { water } \\
\text { n=53 }\end{array}$} & \multicolumn{2}{|c|}{$\begin{array}{l}\text { oxygenated } \\
\text { water } \\
\text { n=55 }\end{array}$} & \multirow[t]{2}{*}{$\rho$} \\
\hline & & $\mathbf{n}$ & $\%$ & $\mathbf{n}$ & $\%$ & \\
\hline \multirow[t]{2}{*}{ Sex } & male & 24 & 45.3 & 20 & 36.4 & \multirow{2}{*}{0.346} \\
\hline & female & 29 & 54.7 & 35 & 63.6 & \\
\hline \multirow[t]{3}{*}{ Age } & $\leq 50 \mathrm{yr}$ & 16 & 30.2 & 19 & 34.5 & \multirow{3}{*}{0.726} \\
\hline & $51-59$ yr & 22 & 41.5 & 24 & 43.6 & \\
\hline & $\geq 60 \mathrm{yr}$ & 15 & 28.3 & 12 & 21.8 & \\
\hline \multirow{2}{*}{ Smoking status } & Yes & 5 & 9.4 & 5 & 9.1 & \multirow{2}{*}{0.951} \\
\hline & No & 48 & 90.6 & 50 & 90.9 & \\
\hline \multirow[t]{2}{*}{ Exercise } & Yes & 33 & 62.3 & 31 & 56.4 & \multirow{2}{*}{0.533} \\
\hline & No & 20 & 37.7 & 24 & 43.6 & \\
\hline \multirow{2}{*}{ Vitamin } & Yes & 10 & 14.2 & 9 & 16.4 & \multirow{2}{*}{0.695} \\
\hline & No & 42 & 80.8 & 46 & 63.6 & \\
\hline \multirow[t]{4}{*}{$\begin{array}{l}\text { Nuritional Status } \\
\left(\mathrm{kg} / \mathrm{m}^{2}\right)\end{array}$} & $\begin{array}{l}\text { Underweight } \\
(\mathrm{BMI}<18,5)\end{array}$ & 1 & 1.9 & 1 & 1.8 & \multirow[t]{4}{*}{0.720} \\
\hline & $\begin{array}{l}\text { Normal } \\
(18,5<\text { BMI }<25)\end{array}$ & 26 & 49.1 & 33 & 60.0 & \\
\hline & $\begin{array}{l}\text { Overweight } \\
(25<\mathrm{BMI}<30)\end{array}$ & 22 & 41.5 & 18 & 32.7 & \\
\hline & $\begin{array}{l}\text { Obese } \\
(\mathrm{BMI} \geq 30)\end{array}$ & 4 & 7.5 & 3 & 5.5 & \\
\hline
\end{tabular}


It is shown that in DM group, there were no significant differences on confounding factors between nonoxygenated water subgroup and oxygenated water subgroup ( $p>0.05$ ). These subgroups were also equal since the beginning of study.

\section{Blood Glucose and MDA}

The measurement was conducted 3 times, at the beginning of the study, after $1^{\text {st }}$ intervention (after consuming the water for 45 days) and after $2^{\text {nd }}$ intervention (after consuming the water for 90 days).

There has not been any established standard normal value of MDA. In order to make one, MDA values of 60 normal subjects (no illness) (men and women equally with age range $25-60$ years old) were determined and used as normal values. Mean value of MDA in normal subjects was $0.180 \mu \mathrm{mol} / \ell$ plasma.

According to Table 3 , there were no significant difference in the decline of Fasting Plasma Glucose (FPG)(insert values) and Post-prandial Glucose (PPG) (insert values) in both subgroups. But within the oxygenated water subgroup there were a significant decline of FPG after $1^{\text {st }}$ (insert values)and $2^{\text {nd }}$ (insert values) interventions $(\mathrm{p}<0.05)$ and the decline for PPG (insert values) was significant after $2^{\text {nd }}$ intervention $(\mathrm{p}<0.05)$.

On the contrary with FG and PPG decline analysis, there were significant reduction of MDA between oxygenated water subgroup(insert values) and nonoxygenated water subgroup (insert values) after $2^{\text {nd }}$ intervention $(\mathrm{p}<0.05)$.

\section{Perception of DM Subjects}

Interviews by questioners showed that most of subjects in the oxygenated water subgroup felt healthier and fresher after consuming oxygenated water $(63.1 \%)$ than before. And about $60.3 \%$ subjects in non-oxygenated water subgroup also felt healthier and fresher after consuming their water.

Nonetheless, other effects like polyuria, numbness, gastric distention and nausea also were reported during the interviews. Twenty percent subjects in oxygenated water subgroup and $13.8 \%$ subjects in non-oxygenated water subgroup complain other effects.

Table 3. Mean Value of Fasting Plasma Glucose (FPG), Post- Prandial Glucose (PPG) and MDA in DM Subjects

\begin{tabular}{|c|c|c|c|c|c|}
\hline \multirow[b]{2}{*}{ Item \& time evalueted } & \multicolumn{3}{|c|}{ Subgroup } & \multirow[b]{2}{*}{$\begin{array}{l}\rho \text { value among } \\
\text { subgroups }\end{array}$} & \multirow[b]{2}{*}{$\begin{array}{c}\rho \text { value on intervention } \\
\text { between oxygenated } \\
\text { water groups }\end{array}$} \\
\hline & $\begin{array}{c}\text { Non- } \\
\text { oxygenated } \\
\text { water }\end{array}$ & $\begin{array}{c}\text { Oxygenated } \\
\text { water }\end{array}$ & Both & & \\
\hline \multicolumn{6}{|l|}{ FPG (mg/dL) } \\
\hline$*$ Beginning $(\mathrm{X} \pm \mathrm{SD})$ & $168 \pm 57$ & $169 \pm 60$ & $168 \pm 58$ & $>0.05$ & \\
\hline$* 1^{\text {st }}$ Intervention $(\mathrm{X} \pm \mathrm{SD})$ & $159 \pm 56$ & $154 \pm 55$ & $157 \pm 55$ & $>0.05$ & $<0.05$ \\
\hline$* 2^{\text {nd }}$ Intervention $(\mathrm{X} \pm \mathrm{SD})$ & $154 \pm 54$ & $140 \pm 53$ & $147 \pm 53$ & $>0.05$ & $<0.05$ \\
\hline \multicolumn{6}{|l|}{ PPG (mg/dL) } \\
\hline * Beginning $(\mathrm{X} \pm \mathrm{SD})$ & $269 \pm 88$ & $273 \pm 97$ & $271 \pm 92$ & $>0.05$ & \\
\hline$* 1^{\text {st }}$ Intervention $(\mathrm{X} \pm \mathrm{SD})$ & $257 \pm 75$ & $263 \pm 81$ & $260 \pm 78$ & $>0.05$ & $<0.05$ \\
\hline$* 2^{\text {nd }}$ Intervention $(\mathrm{X} \pm \mathrm{SD})$ & $168 \pm 57$ & $243 \pm 87$ & $248 \pm 78$ & $>0.05$ & $<0.05$ \\
\hline \multicolumn{6}{|l|}{$\operatorname{MDA}(\mu \mathrm{mol} / \ell) *$} \\
\hline$*$ Beginning $(\mathrm{X} \pm \mathrm{SD})$ & $0.195 \pm 0.083$ & $0.231 \pm 0.009$ & $0.214 \pm 0.087$ & $<0.05$ & \\
\hline$* 1^{\text {st }}$ Intervention $(\mathrm{X} \pm \mathrm{SD})$ & $0.154 \pm 0.070$ & $0.145 \pm 0.059$ & $0.149 \pm 0.064$ & $>0.05$ & $<0.05$ \\
\hline$* 2^{\text {nd }}$ Intervention $(\mathrm{X} \pm \mathrm{SD})$ & $0.181 \pm 0.072$ & $0.137 \pm 0.041$ & $0.158 \pm 0.062$ & $<0.05$ & $<0.05$ \\
\hline
\end{tabular}

\footnotetext{
* Normal MDA at the

beginning: $0.180 \pm 0.060(\mu \mathrm{mol} / \ell$
}

* Comparison of mean value parameter between oxygenated subgroup and non-oxygenated subgroup where performed in the beginning of the study, $1^{\text {st }}$ intervention and $2^{\text {nd }}$ intervention. 
Table 4. DM Subjects Perception

\begin{tabular}{lccccc}
\hline \multirow{2}{*}{ Sensation of subjects } & $\begin{array}{c}\text { non-oxygenated } \\
\text { water group }\end{array}$ & \multicolumn{2}{c}{$\begin{array}{c}\text { oxygenated water } \\
\text { group }\end{array}$} & \multirow{2}{*}{$\boldsymbol{\rho}$} \\
\cline { 2 - 5 } & $\mathbf{n}$ & $\mathbf{\%}$ & $\mathbf{n}$ & $\mathbf{\%}$ & \\
\hline Normal & 15 & 25.9 & 11 & 16.9 & \\
Healthier/refresh & 35 & 60.3 & 41 & 63.1 & \multirow{2}{*}{0.389} \\
Others & & & & & \\
\cline { 1 - 4 } Total & 8 & 13.8 & 13 & 20.0 & \\
\hline
\end{tabular}

\section{DISCUSSION}

Statistical analyses showed reductions of Fasting Plasma Glucose (FPG), Post-Prandial Glucose (PPG) and MDA level in both oxygenated and non oxygenated water subgroup after consuming the water for 45 days and 90 days compared to baseline and after being controlled with confounding factors. There was also significant MDA decline after the1st intervention, compared to baseline. These data indicate that oxidative stress reductions were more obvious in subjects who were having higher level of oxidative stress. Further analyses demonstrate greater effects of oxygenated water in lowering FPG in DM obese subjects after consuming oxygenated water for 45 days. The role of obesity on oxidative stress can not be ascertained. According to Frei \& Higdon (2003) obesity is a condition related to oxidative stress. Obese subjects might be able to have advantages from antioxidant supplements. ${ }^{6}$

Besides the information above, the reductions of FPG were also greater in the DM subjects who are vitamin consumers and drank oxygenated water for 45 to 90 days. Similar results was also found in DM smoking subjects who consumed oxygenated water for 90 days. Greater reductions of MDAlevel was seen in oxygenated water DM subgroup who performed regular exercise after consuming oxygenated water for 45 and 90 days. Other study revealed that consumption of vitamin E was more beneficial to young subjects than the elderly in reducing $\mathrm{MDA}^{7}$ and the study by Purwantyastuti (2000), showed that antioxidant consumption would give greater effects in younger subjects, without any distinction between male and female. ${ }^{8}$ Antioxidants such as vitamin $\mathrm{C}$ and $\mathrm{E}$ have the ability to quench free radicals. Levels of these vitamins may be decreased in diabetes, although others have shown that measures of total radical-trapping antioxidant patameter (TRAP) are reduced in diabetes, with no change in vitamin $\mathrm{E}$ or C levels. ${ }^{9}$ And other study also said, vitamin E is more beneficial for young age subject than old subjects in reducing MDA. While this oxygenated water study showed a better reduction in old subjects.

A free radical is a molecule containing one or more unpaired electrons in its outer shell, rendering unstable and therefore highly reactive. Oxygen containing free radicals or reactive oxygen species are a major source of free radical tissue damage in aerobic organisms - so called 'oxidative stress'. The susceptibility of tissue to oxidative stress is related to the balance between pro-oxidant and oxygen scavenging factors. Increased damage from oxidative stress can therefore be due to an increase in free radical production or a lack of available antioxidant activity.

In Diabetes Mellitus (DM) patients, hyperglycaemia may lead to an increased generation of free radicals via multiple mechanisms. Glucose and other sugars are capable of auto-oxidation, with the resulting formation of reactive oxygen species including superoxide anion, hydroxyl radicals and hydrogen peroxide, which are all capable of causing lipid and protein damage. ${ }^{9}$ Factors that may promote oxidative stress in diabetes include antioxidant deficiencies, glycation and glycoloxidation, and increased production of reactive oxygen species. Bucala and Cerami (1992) showed increased AGE formation in diabetic LDL, with an increase in lipid peroxidation as evidenced by malondialdehyde (MDA) equivalents. ${ }^{2}$ Malondialdehyde is a stable end product of lipid peroxidation, and as such can be used as a marker of oxidative stress. Increased levels have been found in red blood cell membranes of diabetic patients, correlating with poor glycaemic control. In addition, 
circulating levels of malondialdehyde are higher in the plasma of diabetic subjects compared with patients without diabetic, although this way only the case in poorly controlled diabetics in one study. Malodialdehyde (MDA) is one of the most frequently used indicators of lipid peroxydation (Nielsen $\mathrm{F}$ et all, 1997). ${ }^{10}$

Although oxidative stress and cell cycle reentry have been implicated in the onset of later-onset neurodegenerative diseases and clearly occur together at the cellular level in Hq mutant mice, the mechanism by which oxidative stress may lead to cell cycle abnormalities remains unknown. Cumulative DNA damage caused by endogenous free radicals has been suggested to underlie cancer and other age-related disorders, including neurodegeneration. The progressive accumulation of oxidative damaged DNA and the temporal increase in cell cycle reentry in the retina and cerebellum of aging Hq mutant mice are consistent with such a theory (Klein JA \& Ackerman SL, 2003). ${ }^{11}$

In conclusion, The oxygenated water have beneficial effects for those people with DM, further study is required to find out the mechanism on how oxygenated water work in the human body to provide explanations of evidences and there were some suggestion to clinical study in vitamins to compare between young and adult subjects.

\section{Acknowledgment}

On this opportunity the appreciation is addressed to PT. Tirta Alam Semesta for supplying their Airox, oxygenated water in bottle, for this study

\section{REFERENCES}

1. Roger Detels, James McEwen, Robert Beaglehole and Heizo Tanaka. Oxford Textbook of Public Health. Forth Edition. New York: Oxford University Press, 2006; p. 1279-1307

2. Steven P. Marso and David M. Stern. Diabetes and Cardiovascular Disease. Intergrating Science and Clinical Medicine. Philadelphia: Lippincott Williams \& Wilkins, 2004; p. 19-35

3. W. Forth, Olaf Adam. Uptake of Oxygen from the Intestine Experiments with Rabbits. Munich: Eur J Med Res 6 (2001): 488-92.

4. Pallant, Julie. SPSS Survival Manual, 2nd edition : a step by step guide to data analysis using SPSS, 2005

5. Microsoft Corporation. SPSS Advanced Models ${ }^{\mathrm{TM}} 10.0$. Chicago: SPSS Inc, 1999.

6. Jane V. Higdon \& Balz. Frei. Obesity and Oxidative Stres. A Direct Link to CVD? Editorials of Arteriosclerosis, Thrombosis and Vascular Biology. Corvallis, Oregon: American Heart Association, Inc 2003;23:365.

7. Martinez, RMA and Ruiz Torres A. Homeostasis between lipid peroxidation and antioxidant enzyme activities in healthy human aging. In: Mechanisms of Aging and Development. Elsevier Publication. Ireland. 1992:213-22.

8. Purwantyastuti. Relations of lipid peroxides to food habits, selected coronary heart disease risk factors and vitamin $\mathrm{E}$ supplementation in the elderly. PhD Thesis, University of Indonesia, 2000:105-29.

9. John Ross Turtle, Toshio Kaneko, Shuichi Osato . Diabetes in the New Millenium. Sydney: National Library of Australia, 2006.

10. Flemming Nielsen, Bo Borg Mikkelsen, Jesper Bo Nielsen, Helle Rann Andersen, Philippe Grandjean. Plasma Malondialdehyde as biomarker for oxidative stress: reference interval and effects of life-style factors Washington DC. Clinical chemistry 43:7 (1997): 1209-14

11. Jeffrey. A Klein, Susan L. Ackerman. Oxidative stress, cell cycle and neurodegeneration. J. Clin. Invest. 111 (2003) : 785-93. 